\title{
Nursing care systems and complex thought in nursing education: document analysis
}

\author{
Sistematização da assistência de enfermagem e o pensamento \\ complexo na formação do enfermeiro: análise documental
}

Sistematización de la Asistencia de Enfermería

en un currículo integrado: análisis documental

\author{
Josilaine Porfírio da Silva ${ }^{a}$ \\ Mara Lucia Garanhanib \\ Maria Helena Dantas de Menezes Guariente ${ }^{c}$
}

\begin{abstract}
The aim of this study was to analyse the inclusion of the subject Nursing Care Systems (NCS) in nursing education. This study was based on qualitative desk research and it was conducted in a nursing programme in southern Brazil that offers an integrated curriculum with NCS as a cross-cutting theme. Data were collected from September to December 2012, by examining 15 planning and development workbooks on the cross-disciplinary modules of the programme. Analysis was divided into four stages: exploratory, selective, analytic and interpretive reading. The adopted theoretical framework was Complex Thought of Edgar Morin, according to the principles of relevant knowledge. Results were arranged into two categories: NCS as a crosscutting theme in nursing education: the context, the global and the multidimensional; and strategies for teaching, learning and assessment of NCS: the complex. The study contributes to the debate on the importance of teaching NCS as a crosscutting theme in nursing education.
\end{abstract}

Descriptors: Nursing education research. Nursing process. Curriculum.

\section{RESUMO}

0 objetivo deste estudo foi analisar a inserção do tema Sistematização da Assistência de Enfermagem (SAE) na formação do enfermeiro. Pesquisa qualitativa, documental, realizada em um curso de Enfermagem do sul do Brasil, que possui o currículo integrado e tem a SAE como tema transversal. A coleta de dados foi realizada de setembro a dezembro de 2012, e foram examinados 15 cadernos de planejamento e desenvolvimento referentes aos módulos interdisciplinares do curso. A análise deu-se em quatro momentos: leitura exploratória, seletiva, analítica e interpretativa. 0 referencial teórico empregado foi o Pensamento Complexo de Edgar Morin, segundo os princípios do conhecimento pertinente. Os resultados foram organizados em duas categorias: SAE como tema transversal na formação do enfermeiro: 0 contexto, o global e o multidimensional; estratégias de ensino, aprendizagem e avaliação da SAE: o complexo. 0 estudo contribui para a reflexão sobre a importância do ensino da SAE como tema transversal na formação.

Descritores: Pesquisa em educação de enfermagem. Processos de enfermagem. Currículo.

\section{RESUMEN}

El objetivo de este estudio fue analizar la inserción del tema Sistematización de la Asistencia de Enfermería en la formación del enfermero. Investigación cualitativa, documental, realizada en un curso de enfermería del sur de Brasil, que tiene el currículo integrado y la SAE como tema transversal. La recolección de datos se llevó a cabo entre septiembre y diciembre de 2012 y fueron examinados 15 cuadernos de planificación y desarrollo, referentes a los módulos interdisciplinarios del curso. El análisis se dio en cuatro momentos: lectura exploratoria, selectiva, analítica y interpretativa. El referencial teórico fue los principios del conocimiento pertinente del Pensamiento Complejo de Edgar Morin. Los resultados se organizaron en dos categorías: SAE como un tema transversal en la educación de enfermería: contexto, global y multidimensional; estrategias para la enseñanza, aprendizaje y evaluación de SAE: complejo. El estudio presenta la importancia de la enseñanza de la SAE como un tema transversal.

Descriptores: Investigación en Educación de Enfermería. Procesos de Enfermería. Curriculum.
D0l: http://dx.doi.org/10.1590/19831447.2014.02.44538 


\section{口INTRODUCTION}

The use of Nursing Care Systems (NCS) by nurses enables individualized care with satisfactory interventions, which ensures the continuity of care of health service users $^{(1)}$. Consequently, NCS is a method that organizes and qualifies the work of nurses.

Its use, by means of a Nursing Process (NP), a methodological instrument that guides professional care and practice documentation, is mandatory for all public and private healthcare institutions in Brazil, according to a resolution of the Federal Nursing Council (2), and is also the object of several studies ${ }^{(3-4)}$.

Considering that professional practice essentially reflects education, higher learning institutions have the important responsibility of providing the development of skills of all its academic students for NCS. However, in order to achieve this objective, the subject of NCS must acknowledge the complexity of the human condition.

According to the concept of Complex Thought, established in the 1980s by the French thinker, Edgar Morin, it is not possible to conceive fragmented education when the whole is not learned. Knowledge must be separated from the inadequacy of disconnected and divided skills, since only the articulation and organization of skills allows an understanding of the whole. Therefore, knowledge becomes pertinent when education refers to the complex, to the context, in a multidimensional way and within the global concept ${ }^{(5)}$.

The principle of context is based on overcoming the insufficiency of isolated data, as, in order to make sense, they must be situated. In the global scope, the parts must be linked to the whole, while preserving the individual qualities of each part. The multidimensional aspect entails understanding complex units, such as the human being and society, in its different dimensions. Therefore, the complex indicates that different elements are inseparable, they constitute a whole and each part should be linked to the others in an interactive circuit ${ }^{(5)}$.

Thoughts on education pertinent to NCS are of fundamental importance given the need to find strategies that allow meaningful learning and that culminate in the provision of quality care by nurses. Consequently, the course selected for this study was a nursing programme that offers NCS as a cross-cutting theme in all the study years, in a unique educational proposal divided into cross-disciplinary modules that dynamically bring together theory and practice ${ }^{(6-7)}$.

This study sought to answer the following question: How is the topic of NCS distributed in an undergraduate nursing programme? The aim was to identify the implementation of nursing care systematization in the four years of an undergraduate course.

\section{METHODS}

Research was based on a qualitative document analysis of an undergraduate nursing course at a public university in southern Brazil that annually provides 60 vacancies for new students and has been using the integrated curricula for 13 years.

In this educational curricula, content is integrated in cross-disciplinary modules that provide sequences of activities based on key concepts to reach the necessary performance to obtain nursing certification ${ }^{(6)}$. The educational project provides transversal themes that cross curricular content and target expansion of student knowledge. Course professors use the phrase line of investigation to refer to cross-cutting topics ${ }^{(7)}$. Among these lines, there is the Care Methodology, a topic on which this study was based.

Each module provides a planning and development workbook that shows the teaching and learning plan proposed of that specific module. This workbook allows documentation of module operationalization, and the orientation and follow-up of activities to be conducted. The workbook comprises a topic tree that outlines key concepts to be discussed; competencies, performance and skills to be acquired by the students; general and specific conditions; sequence of theoretical and practice activities; schedule; and references.

For this study, a total of 18 workbooks of 2012 were examined for document analysis ${ }^{(8)}$. Data were collected between September and December 2012, after authorization for use and availability of workbooks, by email, of the programme coordinator, and signing of a non-disclosure and reliability-assurance agreement by the researcher.

Once these documents were obtained, the collected material was read four times in the following sequence: exploratory, selective, analytic and interpretive reading ${ }^{(9)}$. During exploratory reading, the workbooks were read in their entirety to find a relationship between content and NCS. During this stage, documents were selected based on the inclusion criteria that the study topic should be present in the workbooks. Three workbooks were excluded because they did not address NCS, resulting in 15 workbooks.

After defining the documents, analytic reading was initiated to order and group data. During this stage, charts for each workbook were created to address competencies, performance, specific skills on NCS, and presence of the topic in theoretical and practice activities and references. 
After grouping data, interpretive reading was conducted to group the obtained information, resulting in two categories that responded to the object of study. The adopted theoretical reference was Complex Thought of Edgar Morin ${ }^{(5,10)}$, according to principles of pertinent knowledge. Document (D) sections presented in this study were randomly identified with Arabic algorithms (D1, D2, ...).

This study was approved by the Research Ethics Committee of a public university, as stipulated in Resolution $466 / 12$ of the National Health Council, under number 84180/2012, according to CAAE 06270612.2.0000.5231. Results presented in this study were obtained from a master's degree dissertation ${ }^{(11)}$.

\section{RESULTS AND DISCUSSION}

Data were grouped into two categories analysed from the standpoint of the pertinent knowledge principles: context, global, multidimensional and complex $x^{(5)}$. These are not sequential or isolated and are presented for educational purposes without the intention of fragmenting or exhausting them.

\section{NCS as a cross-cutting topic in the education of nurses: the context, the global and the multidimensional}

Analysis of the topic of NCS in the module workbooks showed that it is present in all programme years, especially from the second year onwards, when it is formally described. However, all the workbooks, including those of the first year, in some way approach aspects related to this topic. (Chart 1).

In the first year, the workbooks contained references that could be related to learning NCS: interview, physical exam of all systems and intervention plan, as shown in Chart 1 and fragments of the documents:

\section{Create interview script. (D4)}

Relationship of morphophysiological aspects with the main physical exam techniques for patients. (D5)

The process of obtaining information on the person, family or community is the first stage of the NP(2). Considering that data can be collected during interviews or physical examinations, it is understood that, in the first year, students are introduced to this stage, although there is no description in the workbooks of activities that allow an evaluation of educational intention of professors or the relationship of activities developed with NCS.
Consequently, there is a need to clearly explain, when preparing interviews and conducting physical examinations, the relationship of these activities with NCS, since their realization consists of patient evaluations ${ }^{(12)}$.

The physical examination is reintroduced in the subsequent years, but the fact that this topic is addressed in the first year in an isolated manner, without a relationship with NCS, strips it of any relevance, considering that in order to obtain a broader scope, information must abandon an isolated approach and be presented in association with a context ${ }^{(5,10)}$.

The workbooks of the second year of the programme require students to practice in hospital and primary care units, during which they come into contact with NCS in a more effective manner (Chart 1).

Is familiar with Nursing Care Systems, identifies its importance to assure quality of provided care and applies the nursing process stages. (D1)

Although the educational proposal of the integrated curriculum is sustained by successive exposure to context in increasing levels of complexity throughout the programme ${ }^{(6)}$, the lack of connection of the part with the whole compromises thought on that topic and leads to superficiality at the moment of learning.

Content introduced in the first year should be continued in the following year and used as a basis to present new knowledge to students to increase understanding on the topic, since knowledge reaches a broader sense when information is associated to a context $\mathrm{t}^{(5)}$.

In the third year of the programme, the subject of NCS is described in all workbooks. Points to emphasise are discussions on the legal aspects of NCS and professional practice laws. Furthermore, healthcare protocols, a resource based on scientific evidence and epidemiological data, which contribute to the quality of care ${ }^{(13)}$, are also used in nursing consultations (Chart 1).

Discusses Nursing Care Systems in the care of adults and the elderly, addressing the standards and legal aspects of documentation in nursing. (D10)

During this year, the subject of NCS is presented with greater clarity to students. The union of parts, that is, of the stages of NP, to the whole, allow students to also understand the global principle proposed for relevant knowledge. This concept reaches beyond the observance of context. To understand the global implies a pursuit, in the union of parts, of the individual qualities of each of these 


\begin{tabular}{|c|c|}
\hline \multicolumn{2}{|r|}{$1^{\text {ST }}$ YEAR } \\
\hline Cross-disciplinary modules & $\begin{array}{l}\text { The University and the Nursing Course } \\
\text { The Health Sickness Process } \\
\text { Cross-disciplinary practices and practices of Learning, Service and Community Interaction I } \\
\text { Morphophysiological and Emotional Aspects of Human Beings }\end{array}$ \\
\hline Insertion of the NCS topic & $\begin{array}{l}\text { - Interview } \\
\text { - Physical exam } \\
\text { - Intervention plan }\end{array}$ \\
\hline \multicolumn{2}{|r|}{$2^{\text {ND }}$ YEAR } \\
\hline Cross-disciplinary modules & $\begin{array}{l}\text { Care Practices } \\
\text { Organization of Healthcare and Nursing Services } \\
\text { Adult Health I } \\
\text { Material and Biosecurity Central }\end{array}$ \\
\hline Insertion of the NCS topic & $\begin{array}{l}\text { - NCS } \\
\text { - Nursing process } \\
\text { - Nursing diagnosis of the North American Nursing Diagnosis Association (NANDA) } \\
\text { - Nursing theories } \\
\text { - Nursing consultations } \\
\text { - Nursing care planning }\end{array}$ \\
\hline \multicolumn{2}{|r|}{$3^{\text {RD }}$ YEAR } \\
\hline Cross-disciplinary modules & $\begin{array}{l}\text { Adult Health II } \\
\text { Child and Adolescent Health } \\
\text { Women's and Gender Health }\end{array}$ \\
\hline Insertion of the NCS topic & $\begin{array}{l}\text { - NCS } \\
\text { - Nursing process } \\
\text { - Nursing diagnosis of the NANDA } \\
\text { - Prescriptions and Evolution } \\
\text { - Legal aspects } \\
\text { - Nursing consultation } \\
\text { - Use of care protocols }\end{array}$ \\
\hline \multicolumn{2}{|r|}{$4^{\mathrm{TH}}$ YEAR } \\
\hline Cross-disciplinary modules & $\begin{array}{l}\text { Transmissible Diseases: prevention and care } \\
\text { Mental Health: nursing actions at different levels of care } \\
\text { Critical Patient Care } \\
\text { Internship }\end{array}$ \\
\hline Insertion of the NCS topic & $\begin{array}{l}\text { - NCS } \\
\text { - Provide systematized care } \\
\text { - Complete nursing process stages } \\
\text { - NCS applicability } \\
\text { - Care organization planning } \\
\text { - Nursing consultation }\end{array}$ \\
\hline
\end{tabular}

Chart 1. Insertion of the topic of NCS, per year, in the planning and development workbooks of cross-disciplinary modules of the nursing programme, Brazil, 2012.

Source: Authors 
parts, as separating them would also lead to a loss of quality of the global(5).

The isolated approach of NP stages throughout the programme years for the exploration of particular characteristics of each stage is no less important. It is therefore necessary to explore each of these stages to enhance the whole and provide visibility that NCS with quality can be achieved.

In addition to increasing knowledge, there is also an immersion of NCS in the scope of contexts studied in each module involving care provided to human beings during their entire life cycle. An understanding of NCS associated to human beings that is simultaneously biological, emotional, social, affective and rational, contributes to the apprehension of specific phenomena, since it covers the healthcare and sickness process and thus qualifies the education and the care that will be provided by the students ${ }^{(5)}$.

This understanding refers to the multidimensional principle, according to which the parts should not be separated from each other ${ }^{(5)}$. Once again, it is important to connect each topic of NCS learning to the other topics as they are taught, while always going back to the context.

In the fourth year, NCS were also described in all the workbooks. In the second semester, students completed the module of supervised nursing internships that lasted around six months, during which they practiced as nurses in hospital and primary care units (Chart 1).

The development of NCS is enriched during that time because, at the hospital units, it is used by means of PE stages as it is simultaneously discussed in the classroom. Students are urged to reflect on its practice and identify the NCS model that is used in their internship unit.

\section{Discusses the use of NCS in hospital practice. (D7)}

In the primary care units, students also carried out care planning and organization activities, engaged in nursing consultations, and used healthcare protocols although the term NCS was not used.

Conducts a nursing consultation and registers users according to protocol, in the programmes of: childcare, low-risk prenatal care, family planning, cervix and breast cancer control, high blood pressure, asthma and other programmes in the municipality. (D7)

The educational proposal described in that semester was based on maintaining the interconnection of discussions and previous learning, thus allowing the attainment of new skills and conclusion of learning on that subject at the moment of graduation ${ }^{(6)}$. After students were exposed to this topic, the use of NCS as a care management tool and an understanding of its role in the nursing practice process was reinforced $^{(7)}$.

During this year, students had the chance to more effectively practice using NCS and therefore acquired a better understanding of the context, the global and the multidimensional. This occurs in light of the development of NCS in different realities of healthcare services by means of the relationship of nursing process stages, one with the other, and with the various dimensions of the human beings who receive this care.

The adoption of NCS as a line of investigation in the educational proposal of the programme enables the pursuit of pertinent learning described in Complex Thought ${ }^{(5,10)}$, that is, a profound and concise knowledge that allows an understanding of the context, the union of the parts to the whole and of the whole to the parts, and recognition of the multidimensional. The professors should therefore help students to understand NCS as a complex unit.

This topic evidently permeates all the years of the programme in varying levels of intentionality and new aspects are added to the discussions every year. This characteristic can enable the construction of more significant and current discussions that lead students to critical and reflexive thought, allowing a greater understanding and incorporation of this important activity.

\section{Teaching, learning and evaluation strategies of NCS: the complex}

In addition to permeating all the programme years, several learning strategies are used to ensure that the topic of NCS is learned in a more significant manner: diversity in the fields of practice, problem resolution, case studies, reference lists and evaluation.

In order to reach pertinence, knowledge must pursue the complex, considering that different elements are inseparable and constitute the whole ${ }^{(5)}$. Similarly, the learning of NCS is also related to the manner in which the topic is presented, discussed and used by students.

Throughout the course, NCS is discussed in the classroom and later developed in the different practice fields consisting of clinical, surgical, mother and child, emergency and intensive care hospital units, infectious disease units, family health and psychosocial care units, out-patient units, and others.

Provides systematized nursing care to individuals with transmissible diseases using clinical, epidemiological and investigative reasoning. (D15) 
The use of different scenarios is a facilitating factor of the NCS knowledge construction process because these environments provide an immersion into different realities. For students, this awakens a vision that, beyond the need of physical health, includes the social, political and historical context in which the human being is inserted, allowing a significant learning experience and enhancing the relationship between theory and practice ${ }^{(14,6)}$.

Theoretical discussions are based on the questioning of reality, that seeks the critical construction of knowledge. The professors urge students to actively and critically search for answers to problems identified in the context in which they are inserted to acquire the necessary competencies to solve these problems ${ }^{(6)}$.

In some modules, there are reserved areas for discussing practice activities, in the classroom, and to present case studies that observe NP stages. These activities favour the possibility of rethinking reality and acquiring problem-solving skills to enhance the use of NCS.

Discuss physical and psychomotor characteristics of children observed and recorded during physical examinations. (D3)

The union of theory and practice and the use of active methodologies are strategies that help students contextualize the subject and the learning experience. Students assume the key role in building knowledge and their actions are based on the acquired theoretical knowledge, which results in a meaningful learning experience ${ }^{(14)}$.

The unique difference, in relation to theory and practice and the contextualization of knowledge by students, lies in the pursuit of intelligence that is contrary to the concept of reductionism, considering that separating the object and the context hinders the relationship between the two by preventing an understanding of the whole, which constitutes the complex ${ }^{(5)}$.

The study of NCS in this learning method aims to provide more meaning to experiences and practices of students to the detriment of the theoretical dimension, which results in greater acceptance of and adherence to NCS by students.

The substantiation of students is still based on a list of available references in each workbook. Throughout the course, content becomes more detailed and specific: it starts with references on interviews and physical examinations and covers all the nursing process stages. In the final years, in addition to the structural aspect, the subject of NCS is also addressed according to the different healthcare needs of each study group, finally leading to the concept of the care management instrument.
The provided references are mostly books, withal, analysis revealed the use of classic literature on NP, which does not invalidate the need for updates, considering that scientific production on NCS has been increasingly expressive and has covered several aspects: implementation and operationalization, instruction on NCS and NP, relationship between NCS and the quality of care, among other topics $115,16,3)$.

The revision of references is therefore necessary in light of advancements in the understanding and implementation of this theme in professional practice fields and nursing schools. These advancements are fundamental, since knowledge should not be reductionist or unattached to reality, given that the restriction of the complex in favour of the simple would impair learning ${ }^{(5)}$.

References on NCS were also found in the first-year workbooks. These, however, did not have activities that connected NCS to other actions, such as interviews and physical examinations. This gap must be remedied so students can make better use of the content and reach a broader understanding of this knowledge.

Documentation on the evaluation techniques and procedures of students in relation to NCS is restricted to some activities, such as presenting case studies and creating care system roadmaps. This reveals the need to improve this record, since, in the integrated curriculum, the evaluation process targets continuous supervision of the students learning experience, which requires engagement of students so they can acquire relevant knowledge ${ }^{(6)}$.

The method used to evaluate student competencies, performance and skills should be included in the documents, so that students themselves can accompany their learning process and try to meet the necessary requirements to understand NCS in each module.

Although some points need to be perfected, results shown in this category indicate that the strategies adopted for teaching NCS allow pertinent teaching because they refer to relevant learning.

\section{GINAL CONSIDERATIONS}

This study revealed that the subject of NCS developed as a line of investigation in the integrated curriculum permeates all the programme years by means of theoretical activities, followed by practice in different scenarios.

The basis of Complex Thought allowed a better understanding of the impairments of teaching that does not contextualize and does not connect the parts or the parts to the whole. We can conclude that the cross-cutting approach to NCS enables a better understanding of the subject and should be extended to other nursing schools, 
considering the need to narrow the gaps that fragmented content can create in teaching and to pursue pertinent knowledge in education.

Furthermore, some suggestions should be considered in relation to the teaching of NCS: updating of references provided in the workbooks; greater integration between the stages of NP and NCS presented in the first year; and extended evaluation documentation of this content.

The characterization of activities for the teaching of NSC contributes to the organization of the studied nursing programme and of other courses, allowing improvements in the practices of the future professionals and in the quality of patient care. However, there is need for new studies that present the view of students and professors of the programme on teaching NCS, since this study is limited due to research based solely on books.

We hope this study can encourage nursing schools to pursue similar initiatives, with constant exposure to NCS throughout the course to obtain better acceptance and adhesion of nurses with regards to its use. It can also create awareness of nursing professors on the importance of approaching the subject of NCS based on active methodological strategies that help to provide meaning to the learning experience.

\section{REFERENCES}

1. Medeiros AL, Santos SR, Cabral RWL. Sistematização da assistência de enfermagem na perspectiva dos enfermeiros: uma abordagem metodológica na teoria fundamentada. Rev Gaúcha Enferm [Internet]. 2012 [citado 2013 maio 12];33(3):174-81. Available in: http://www.scielo.br/scielo.php?pid=\$1983$-14472012000300023 \&$ script=sci_arttext.

2. Conselho Federal de Enfermagem (BR). Resolução COFEN n. 358, de 15 de outubro de 2009: dispõe sobre a sistematização da assistência de enfermagem e a implementação do processo de enfermagem em ambientes, públicos ou privados, em que ocorre o cuidado profissional de enfermagem, e dá outras providências. Brasília (DF); 2009 [citado 2012 maio 04]. Available in: http://site. portalcofen.gov.br/node/4384.

3. Duran ECM, Toledo VP. Análise da produção do conhecimento em processo de enfermagem: estudo exploratório-descritivo. Rev Gaúcha Enferm [Internet].
2011 [citado 2013 maio 10];32(2):234-40. Available in: http://www.scielo.br/ scielo.php?pid=S1983-14472011000200004\&script=sci_arttext.

4. Huitzi-Egilegor JX, Elorza-Puyadena MI, Urkia-Etxabe JM, Zubero-Linaza J, Zupiria-Gorostidi X. Uso del proceso de enfermería em los centros públicos y privados de un área de salud. Rev. Latino-Am. Enfermagem [Internet]. 2012 [citado 2013 maio 12]; 20(5): [06 telas]. Available in: http://www.scielo.br/ pdf/rlae/v20n5/es_12.pdf.

5. Morin E. Os sete saberes necessários à educação do futuro. 10. ed. São Paulo: Cortez; 2005.

6. Garanhani ML, Vannuchi MTO, Pinto AC, Simões TR, Guariente MHDM. Integrated nursing curriculum in Brazil: a 13-year experience. Creative Educ [Internet]. 2013 [citado 2014 jan 28];4(12B):66-74. Available in: http://dx.doi. org/10.4236/ce.2013.412A2010.

7. Guariente MHDM, Kikuchi EM, Carvalho WO, Vannuchi MTO, Dessunti EM, Gastaldi $A B$, et al. Seivas do currículo integrado de enfermagem. In: Kikuchi EM, Guariente MHDM, organizadoras. Currículo integrado: a experiência do curso de enfermagem da Universidade Estadual de Londrina. Londrina: UEL; 2012. p. 93-128.

8. Sá-Silva JR, Almeida CD, Guindan JF. Pesquisa documental: pistas teóricas e metodológicas. Rev Bras Hist Cienc Soc [Internet]. 2009 [citado 2012 maio 29];1(1):1-15. Available in: http://www.rbhcs.com/index_arquivos/Artigo. Pesquisa\%20documental.pdf.

9. Gil AC. Como elaborar projetos de pesquisa. 5. ed. São Paulo: Atlas; 2010.

10. Morin E, Almeida MC, Carvalho EA, organizadores. Educação e complexidade: os sete saberes e outros ensaios. 5. ed. São Paulo: Cortez; 2009.

11. Silva JP. Sistematização da assistência de enfermagem na formação do enfermeiro: um olhar sob o pensamento complexo [dissertação]. Londrina (PR): Universidade Estadual de Londrina; 2013.

12. Santos N, Veiga P, Andrade R. Importância da anamnese e do exame físico para 0 cuidado do enfermeiro. Rev Bras Enferm. 2011;64(2):355-8.

13. Conselho Regional de Enfermagem de São Paulo (BR). Parecer COREN-SP 018/2012: Parecer sobre protocolo de enfermagem em saúde da mulher elaborado por Secretaria Municipal de Saúde [Internet]. São Paulo (SP); 2012. Available in: http://portal.coren-sp.gov.br/sites/default/files/parecer_coren_ sp_2012_18.pdf.

14. Paranhos VD, Mendes MMR. Competency-based curriculum and active methodology: perceptions of nursing students. Rev Latino-Am Enfermagem [Internet]. 2010 [citado 2013 maio 10];18(1):[07 telas]. Available in: http://www. scielo.br/pdf/rlae/v18n1/17.pdf.

15. Venturini DA, Matsuda LM, Waidman MAP. Produção científica brasileira sobre sistematização da assistência de enfermagem. Cienc Cuid Saúde. 2009;8(4):70715.

16. Salomão GSM, Azevedo RCS. Produção bibliográfica sobre o processo de enfermagem. Acta Paul Enferm. 2009;22(5):691-5.

\section{Author's address:}

Josilaine Porfírio da Silva

Rua Ernesto Angelo Guasti, 298, Cambé IV

86183-350, Cambé, PR

E-mail:josi_laine1@yahoo.com.br
Received: 09.01.2014

Approved: 28.02.2014
134

Rev Gaúcha Enferm. 2014 jun;35(2):128-34. 